\title{
Utilization of Marine Fisheries Resources to Meet the Economic Needs of the Community in Latdalam Village, South Tanimbar District
}

\author{
${ }^{1}$ Aksilas Dasfordate* \\ History Education Department, \\ Faculty of Social Science \\ Universitas Negeri Manado \\ Tondano, Indonesia \\ aksilas.unima@gmail.com
}

\author{
${ }^{2}$ Yohanes Burdam \\ History Education Department, \\ Faculty of Social Science \\ Universitas Negeri Manado \\ Tondano, Indonesia \\ burdamyohanes@gmail.com
}

\begin{abstract}
The purpose of this study is to explain the economic life of coastal communities in Latdalam village, Tanimbar Selatan sub-district, to describe the marine fishery resource management system in Latdalam village, Tanimbar Selatan sub-district, and to analyze the primary reasons for traditional fishers in Latdalam village, which are still surviving in traditional ways. With simple equipment in fishing activities in the sea. This research uses a qualitative descriptive approach. The marine fishery resource management system in Latdalam village can be seen in empowerment through the development of collective action, which means the development of cooperatives or joint business groups. Only here, the term used is collective action, namely to open opportunities for the community to form groups they want, which are not merely cooperatives or joint business groups. Collective action is a collective action that leads to the welfare of each member. Efforts to develop collective action carried out so far are through the development of religion-based groups such as Islamic boarding schools cooperatives. Groups allied with certain NGOs that do have staff and funds for coastal community development have also been developed. The groups that also received attention were the women or girls group. The application of the Grameen bank model with a focus on fisherwomen was developed in Bekasi and the Thousand Islands in 2000, and in 2001 it was also developed in Saumlaki, West Southeast Maluku. Besides, the collective action of women who process fish is also developed so that they can quickly obtain production inputs and sell their processed products at a better price. The development of this collective action is still premature and requires studies to find forms that are truly useful for society. Some of the collective actions that have developed are not as pure ideas and ideas as the community in Latdalam village. Finally, collective or semi-collective actions such as the people's core fisheries and business partnerships between the community and big entrepreneurs only bring dissatisfaction to the community and stop in the middle of the road. This occurs because the semi-collective action has a strong influence on the interests of entrepreneurs.
\end{abstract}

Keywords: Resources, Fisheries, Sea, Economy, Community, Latdalam

\section{INTRODUCTION}

The territorial waters of Indonesia contain abundant and diverse natural resources, especially biological resources (fish). According to the National Commission for the Study of Marine Fisheries Resources (1998), the potential for marine fish resources in all Indonesian waters is estimated to be 6.26 million tons per year. This means that the level of utilization of marine fish resources in Indonesia has only reached $58.80 \%$.

The development of coastal areas is generally associated with poverty alleviation efforts for fishers whose lives depend on fisheries. In essence, the fishery sector can be developed as an alternative to improving the fishermen's economy. The fishing community is one of the many economically vulnerable groups. This problem must be resolved by utilizing all the potential or available resources and supported by the implementation of effective strategies. Effective strategies can be achieved through the use of technology, labor incentives, capital and skills, and institutional empowerment to increase the income of the poor.

The utilization of marine fish resources in various regions in Indonesia is not evenly distributed. In some areas, especially in the waters of Eastern Indonesia, there are still great opportunities for the development of their utilization, while in the waters of Western Indonesia, it has reached a position of "overfishing" or overfishing. This can be caused because the management of potential fishery resources is not carried out in an integrated manner. One of the causes is the unavailability of information on the potential of fishery resources in Indonesian territory, which by itself implies less optimal utilization of fishery resources in Indonesia. Lack of data and information causes fishery potential not to be utilized optimally while maintaining environmental sustainability.

In general, traditional fishers in this paper are fishermen who utilize marine fishery resources with traditional fishing gear, small business capital, and relatively simple sighting organizations. In daily life, traditional fishers are more oriented towards fulfilling their own needs. This means that the catch allocation that is sold is used more to meet basic daily needs, especially food, and not invested in developing a business scale. This is inversely proportional to modern fishers who respond more to changes, especially regarding fishing conditions. Traditional fishers often experience a process 
of marginalization (marginalization) so that they become victims of development programs, especially fisheries modernization, which are a-historical. As a result, the space for traditional fishers is generally minimal, especially the fishing area, which only covers the inshore (coast).

In this context, in general, the West Southeast Maluku district (after this abbreviated as MTB district) is included in the epicenter of the world marine biodiversity. This position is possible because of its strategic location between the two oceans (Pacific and Indian). Geographically, this position forms a bioecoregion within a coral triangle network along with other marine areas in the world. The position of the Banda sea, which is directly related to the island sea in the MTB area is very beneficial because it guarantees, 1) a continuous level of water fertility and 2) is a barrier to threats to marine habitats by extreme climatic changes (rising sea surface temperatures due to El- Nino).

The area of this regency is 125,442 kilometers, consisting of a sea stretch of $110,838.4 \mathrm{~km}$ and a land area of $14,584 \mathrm{~km}$ or $88.37 \%$ of the sea area. The inhabitants inhabit 88 of the 133 islands scattered in West Southeast Maluku Regency. The sea area contains a number of resources that can be used directly or indirectly. Resources consisting of renewable (biological) resources but also non-renewable (non-living) resources such as waves, wind, minerals, and various marine services that can be developed. The marine area of the MTB is also part of the residential area (home) and almost 10 times the number of coral reef species in the Caribbean (atlantic) sea. Apart from that, it is part of the waters of Eastern Indonesia which holds nearly $0.25 \%$ of the world's fish species. This wealth is spread across the four existing archipelagic groups so that it is expected to act as a superior production center. However, until now, this wealth potential has not been utilized maximally and adequately for the welfare of the MTB community.

In general, fishermen in MTB, mostly traditional fishermen in Latdalam village, Tanimbar Selatan subdistrict, still experience limited fishing technology. With simple fishing gear, the operational area is limited, only around coastal waters. Besides, the dependence on the "season" is very high so that they are not able to go out to sea all the time, especially during the wave season, which can last for more than one month. As a result, apart from the limited catch, with the simplicity of the fishing gear, they have, in particular, seasons no catch can be obtained. This condition is detrimental to fishers because, in real terms the average income per month is smaller and the income earned during the fish season will be consumed during famine.

Management of marine fishery resources in Latdalam village usually depends heavily on changing seasons. In general, there are two seasons in Indonesia, namely the rainy season and the dry season. In the eastern part of Indonesia, the "rainy" season usually lasts from October to April, this season for the Tanimbar community including Latdalam villagers is the "west season". Meanwhile, the "dry" season lasts from May to September which the local community calls the "eastern season". Basically, the number of fish in the east season and the west season is the same, but in the east season, fishermen have better results, because it is supported by a number of factors, such as the weather factor where this season the wind blows from the east, with waves that are not too big. On the other hand, in the western season, the fishermen's catch will decrease due to the instability of the weather, which makes it difficult for fishers to go to sea.

Season dependence is closely related to fishing season and famine. In certain seasons the fishing community cannot carry out fishing activities. Therefore this community has relatively low productivity compared to the agricultural / land community. The advantage of land / agrarian communities is that they are slightly better able to adapt to changing seasons by cultivating different plant varieties. On the other hand, fishing communities are relatively more challenging to adapt to the seasons, especially for fishers who still rely on traditional capture fisheries technology. It can be said that the productivity of fishing communities is relatively lower than that of agrarian/mainland communities.

Excessive use of fishery resources can result in the degradation of these resources. So far, the impact of degradation has been considered a mere ecological phenomenon. However, the broader impact of degradation includes the reduction in social welfare that people should enjoy from the services of goods and services from fishery resources. One of the most fundamental things and the primary concern of any development of natural resources is the magnitude of the welfare impact resulting from the extraction and depreciation of natural resources itself. Welfare is measured from the social benefits generated from natural resources. This measurement is ex-ante, so it is difficult to use it to measure the welfare of environmental damage and depreciation of useful resources.

Fishery resource management planning that considers the estimated relative impacts and human and natural factors on the resource stock to be managed. By taking into account all existing real values, in the end, the right solution can be found. Capture fisheries are a unique economic activity when compared to other activities. This is related to the condition of fish and marine resources themselves, which are often considered as common-pool resources. These characteristics often cause externalities problems among fishers as a result of the independent production process of each fisher, where the catch of one fisherman will depend heavily on the condition of fish resources, which is a function of the externalities of various other non-production activities, 
apart from fisher production activities, such as the condition of the water quality itself.

Another thing that is unique about capture fisheries is that it is usually regulated in quasi-open access conditions, which makes it challenging to control input factors so that in the end, it is difficult to measure how much fishery capacity is allocated in a water area. In this condition, it is difficult for us to know whether the fishery is in a state of overcapacity and under capacity.

MTB has a sufficient potential coastal and marine water management area but has not been used optimally. The number of fishers is relatively constant, while the number of boats without a motor tends to decrease from year to year. On the other hand, the number of outboard motors and motorboats tends to increase from year to year. However, it should be understood that the majority (more than $85 \%$ ) of fishers still rely on boats without motors.

28,942 fishermen in 2018 carried out fishing activities using boats without motors, 13623 units, boats/boats with motorized 4,080 units, outboard motors 2,169 units, and motorboats 241 units. (source: MTB in Figures 2017/2018). The primary/dominant fishing gear used by fishermen is generally still traditional, starting from other fishing gear, gill nets, and traps. Other fishing tools that are less in number are charts, scoops, and trawlers. This shows that fishers are only able to catch fish at specific depths and in certain seasons. Revitalization of fishing gear is needed to empower traditional fishers in the MTB district, mostly traditional fishers in Latdalam village.

The focus is limited to "management of marine fisheries resources and efforts to alleviate poverty in coastal communities in Latdalam village, Tanimbar Selatan sub-district." This problem is further formulated as follows:

1. How is the economic life of the Pesisr community in Latdalam village, Tanimbar Selatan sub-district?

2. How is the marine fishery resource management system in Latdalam village?

3. Why do traditional fishers in Latdalam village still use traditional methods with traditional fishing equipment to catch fish

\section{RESEARCH METHODS}

In this study, researchers chose to use a qualitative descriptive approach. Qualitative research is a method for exploring and understanding the meaning of several individuals or groups of people ascribed to social or humanitarian problems. This qualitative research process involves essential efforts, such as asking questions and procedures, collecting specific data from participants, analyzing data inductively starting from specific themes to general themes, and interpreting the meaning of data. According to reference [1], data collection techniques are the most strategic step in research because the primary purpose of the research is to obtain data. Without knowing data collection techniques, the researcher will not get data that meets the established data standards. In this regard, the data collection techniques that will be used by researchers in this study are: Observation, Interview, Documentation, and literature study. In conducting data analysis, researchers will immediately process and analyze the data collected so that the data obtained does not accumulate. In testing the validity of the data, the researcher will use internal validity (credibility) in the aspect of truth value, in its application in terms of external validity (transferability), and reliability (dependability) in the aspect of consistency, and objectivity (confirmability) in the naturalist aspect. In qualitative research, the level of validity is more emphasized on the data obtained. The confidence of the research data can be said to have a significant influence on the success of a study.

\section{RESULT AND DISCUSSION \\ A. The Concept of Coastal Communities}

From the title of this paper, three keywords should be observed, namely (1) population and socio-economic aspects, (2) community empowerment strategies, and (3) integrated coastal management. The relationship or relationship between these three keywords has been disclosed in the title of this paper. It can be seen that the socio-economic aspects of coastal communities and their empowerment efforts are essential variables in developing integrated coastal resource management. How the relationship between these variables looks like and what is the essence of the relationship between these variables will be described in this paper. However, first, we will describe the socio-economic aspects and strategies for empowering coastal communities. At the end of this paper, several examples of coastal community empowerment activities are proposed and their implications for the development of integrated coastal area management.

For this paper, the population of coastal communities is defined as a group of people who live in coastal areas and whose economic livelihood depends directly on the use of marine and coastal resources. Even this definition can also be developed further because, basically, many people whose lives depend on marine resources. They consist of owner fishers, fisherman laborers, fish and other marine organism cultivators, fish traders, fish processors, fishery production facility suppliers. In the non-fishery sector, coastal communities can consist of sellers of tourism services, sellers of transportation services, and other community groups who use marine and coastal non-biological resources to support their lives [2].

However, more of them are subsistence, running their businesses and economic activities to support their own families, on a scale so small that the results are only sufficient to meet very short-term needs. In terms of the scale of fisheries business, the low coastal community 
groups include fishery households that catch fish without using boats, use boats without motorbikes and motorized boats. With this business scale, this household is only able to catch fish near the coast. In some instances, they can indeed go further from the coast by working together as partners of large companies. However, there are not so many business partnerships and meaningful compared to a large number of households. Poverty, which is an indicator of the underdevelopment of coastal communities, is caused by at least three main things, namely (1) structural poverty, (2) super-structural poverty, and (3) cultural poverty.

Structural poverty is poverty caused by the influence of external factors or variables outside the individual. These variables are the socio-economic structure of the community, the availability of development incentives or disincentives, the availability of development facilities, the availability of technology, and the availability of development resources, mostly natural resources. The relationship between these variables and poverty is generally inverse. This means that the higher the intensity, volume, and quality of these variables, the less poverty will be. Especially for the socio-economic structure variables, the relationship with poverty is more difficult to determine. What is clear is that the socio-economic conditions of the community that occurs around or within the fishermen's scope determine their poverty and welfare. Super-structural poverty is poverty caused by macro policy variables that are not so strong in favor of fishermen's development [3].

Cultural poverty is poverty caused by variables that are inherent, inherent, and become a particular lifestyle. As a result, it is difficult for the individual to get out of poverty because it is not realized or not known by the individual concerned [4]. The variables that cause cultural poverty are the level of education, knowledge, customs, culture, belief, loyalty to individual views, and obedience to role models. This structural poverty is difficult to overcome. In general, the influence of role models (patron), both formal, informal, and indigenous, greatly determines the success of these cultural poverty alleviation efforts. Research in several Asian countries whose societies consist of several religious groups also shows that religion and community belief values have a very significant influence on the socio-economic status of the community and family. Resource economists see that poverty in coastal communities, especially fishermen, is mostly due to socio-economic factors related to the characteristics of the resources and technology used. These factors keep fishers in poverty.

Smith, who conducted studies on fisheries development in various Asian countries, and Anderson (1979), who conducted it in European and North American countries, concluded that the fixity and rigidity of fishing assets were the main reasons why fishers remained or struggled with fishing assets [5]. Poverty and there seems to be no effort to get out of it. The rigidity of these assets is due to the nature of fishery assets, which are such that they are difficult to liquidate or change their form and function to be used for other purposes. As a result, when the productivity of these assets is low, fishers are unable to transfer or liquidate these assets. Therefore, even though productivity is low, fishers still carry out fishing operations that are no longer economically efficient. Subade and Abdullah (1993) put forward another argument, namely that fishers remain in the fishing industry because of their low opportunity costs. Fishermen's opportunity cost, by definition, is the best possibility or alternative of economic activity or business that can be obtained other than fishing. In other words, the opportunity cost is another possibility that fishers could work on if they did not catch fish. If the opportunity cost is low, fishers tend to continue their business even though the business is no longer profitable and efficient. There is also an argument that the opportunity cost of fishers, especially in developing countries, is minimal and tends to be close to zero. If so, fishers will have no other choice for their livelihood. Thus what happens, fishers continue to work as fishermen because that is all they can do [6].

Panayotou (1982) states that fishers still want to live in poverty because of their desire to live that life (preference for a particular way of life). This opinion of Panayotou (1982) is condensed by reference [7] emphasizing that fishers prefer to have the satisfaction of life they can get from fishing and not act as actors who are solely oriented towards increasing income. Because of such a way of life, whatever happens to his situation, it is not considered a problem for him. The way of life is complicated to change. Because of that, although according to other people's views, fishers live in poverty, for fishers, it is not poverty, and they may feel happy with that life.

\section{B. Alleviating Poverty Coastal Communities}

Various programs, projects, and activities have been carried out to alleviate fishers from poverty. However, as described above, it turns out that the number of small fishers continues to increase in magnitude. The coastal villages are getting bigger and bigger every day. Therefore, although many attempts have been made, it can generally be said that these efforts have not brought satisfactory results. The motorization of small-scale fishing fleets is a program developed in the early 1980s to increase productivity. The motorization program was implemented in areas with high fishing grounds, as well as a response to the issuance of Presidential Decree No. 39 of 1980 regarding the elimination of the tiger amazement. This program is a kind of compensation to increase national shrimp production. However, it turned out that the motorization of these fleets failed because they were not well targeted, namely bias against small 
fishers, manipulated by the authorities and elites for their interests and not for the benefit of fishers.

However, this motorization program also had a positive impact, seen from the increase in the number of motorized boats in many regions in Indonesia. Currently, if there is a government program to set up a fishing boat/boat fleet, or if there is an investment plan by fishers, the fishermen's request is always to procure motorboats. Another program developed to alleviate poverty is the development of added value through the application of a cold chain system. The cold chain system is the application of methods of handling fish using ice to avoid deterioration of the quality of the fish. It is said that the cold chain system is due to its essence, namely using ice along the chain of marketing and transportation of fish, namely from the time it is caught or lifted from the sea until the fish arrives at the retail market or in the hands of consumers. Cold chain systems were developed throughout Indonesia in the early 1980s. However, the problem faced is that the socialization of this system is not so good that it ultimately does not have a place in the hearts of the people. For example, to date, in certain areas in Maluku and NTT, there is an opinion that fish that use ice are low-quality fish. For the people in these two areas, even though the fish are of low quality, they are still consumed if they are not cooking ice. Conversely, even though the quality is still useful if you use ice, the fish will not be bought by the public.

One of the programs carried out during the Habibie administration was Protekan 2003, namely the Movement to Increase Fishery Exports until, by 2003, it reached an export value of 10 billion dollars. This movement, however, died at a very young age, in line with the end of the Habibie era. Other programs are related to environmental conservation and rehabilitation. Making artificial corals, replanting mangrove forests, conserving Marine Kasawan, and certain types of fish, as well as law enforcement against fishing activities using bombs, poison, and destructive fishing gear, are development programs that indirectly affect the welfare of fishers. From the institutional side, fisheries business patterns are also developed, which can increase fishermen's income. Over time, many fishing institutions have slowly died and become non-functional. Likewise, many fishers and large corporate partnerships have not continued due to inequities in revenue sharing, risks, and costs. On the contrary, the pattern of a partnership between fishers and the private sector is something that is considered harmful by fishermen, and fishers reject this excellent concept. There are no significant marks and impacts. If so, then there is something wrong with these programs. Alternatively, what is done is not according to need. So other needs are the key to the problem. If this can be resolved and there are development programs in that direction, perhaps fishermen's income as the main component of coastal communities can be increased, and the incidence of poverty can be minimized.

Fishermen poverty alleviation programs can be carried out as follows: (1) Motorization of fishing fleets (2) Use of ice and cold chains (3) Procurement of infrastructure (4) ports (5) Environmental rehabilitation (6) Development of fisheries cooperatives

Development of collaborative business groups

Development of business partnerships.

\section{Fishermen's Activities in Latdalam Village}

Coastal communities are pluralistic societies, communities that are already mixed up with each other. The coastal community environment is not only inhabited by people who make a living in the fisheries and marine sectors. This community is built from several elements of society with different livelihood backgrounds.

Coastal communities have experienced full acculturation as well as land communities. However, most of the activities of these community members are still connected to their livelihood activities. Their activities show their determination and, at the same time, become their identity as coastal communities. Coastal communities have distinctive characteristic patterns in living their lives. Coastal communities tend to have relatively violent attitudes and behaviors that usually appear in the form of behavior in their daily lives. This is a form of adaptation that fishers must do in their daily lives to fight against the threat of ferocious sea waves. The breadth of the home range for fishermen's livelihoods also forms an impression of the harshness of life for fishers.

According to reference [8], the characteristics of coastal communities are unique. This is closely related to the nature of the fisheries business itself, which is highly dependent and influenced by environmental, seasonal, and market factors. Therefore, the characteristics of coastal communities are also influenced by these factors. Therefore, the uniqueness of coastal communities is influenced by these factors, which in turn form a culture of dependence on life that arises naturally.

Fishery business is very dependent on ideal aquatic environmental conditions. This situation has direct implications for the socio-economic conditions of coastal communities. Because fisheries business is very dependent on the water environment, the characteristics of the life of coastal communities depend on the environment and are very vulnerable to environmental damage. Another example is the condition of the capture fisheries business in the Java waters; even though it has exceeded the maximum sustainable yield or in other words, it becomes unproductive for fishers, but it is still famous as a source of their livelihood. Another example is the cultivation of seaweed and fish resources, which are highly dependent on the health of the aquatic environment. 


\section{a. Fishery Fleet}

The utilization of marine and fishery resources through fishing activities is still not optimal. This is mainly due to the structure of the fishing fleet, which is still dominated by small-scale or traditional capture fisheries with relatively low capital capacity and science and technology (HR). Most of the fishermen (80.99\%) up to now still rely on motorless boats with movers such as sails and oars (Table 2.3). In this condition, the fishing operation by fishers is minimal and the fish catch obtained is also low. Apart from that, subsistence and side-by-side management also affect fishing activities that are not yet optimal. If conditions like this continue continuously, it will be difficult for the level of income and welfare of fishers to increase.

Table 2.Number of Fishery Fleets by Village in South Tanimbar District in 2018

\begin{tabular}{|c|c|c|c|c|}
\hline No & Village & $\begin{array}{c}\text { Name } \\
\text { Boat } \\
\text { without } \\
\text { Motor }\end{array}$ & $\begin{array}{c}\text { Boat } \\
\text { Motor }\end{array}$ & $\begin{array}{c}\text { Boat } \\
\text { Outboard }\end{array}$ \\
\hline 1 & Latdalam & 1.112 & 118 & 9 \\
\hline 2 & Lermatang & 516 & 87 & 6 \\
\hline 3 & Matakus & 612 & 90 & 4 \\
\hline 4 & Olilit & 410 & 48 & 4 \\
\hline 5 & Bomaki & 154 & 27 & 2 \\
\hline 6 & Sifnana & 139 & 19 & 2 \\
\hline & Total & $\mathbf{2 9 4 3}$ & $\mathbf{3 8 9}$ & $\mathbf{2 7}$ \\
\hline
\end{tabular}

Source: Maluku Tenggara Barat Dalam Angka (2018)

\section{b. Fishing Tools}

Fishing gear is the essential equipment in the capture fisheries business. Tools are like life for fishers. Every fishing vessel naturally has relatively good availability of fishing gears in each fishing fleet, either using katinting boats or large vessels. Every ship should be equipped with fishing gear. It is strange if the boat or ship does not have minimum fishing gear. However, this fact is indeed found in the realities of the life of our coastal communities.

Most small fishers only have katinting boats and fishing tools. Not a few small fishermen use their katinting boats not equipped with motorbikes, and even many fishers are without boats. Only large fishers use motorized boats and are usually equipped with an average of 3 types of fishing gear; shrimp trawl, gillnet, trammel net, or others. The BPS report (2000) states that there are $1,480,124$ or as many as $81.67 \%$ of families who run small-scale fishing businesses, which consist of $13.7 \%$ of fishers without boats, $59.6 \%$ of non-motorized boats, and motorboats. Paste as much as $26.7 \%$. Meanwhile, fishery households that use motorboats are only $18.33 \%$ or as many as 33,212 families.

For fishing communities in Latdalam village generally, they use fishing gear consisting of beach trawlers, gill nets, charts, traps, and fishing rods. The average catch rate for beach trawlers is estimated at $50 \mathrm{~kg}$
/ trip, gill nets $50 \mathrm{~kg}$ / trip, $100 \mathrm{~kg}$ / trip, sero $40 \mathrm{~kg}$ / trip, $3 \mathrm{~kg}$ traps / trip and $30 \mathrm{~kg}$ fishing rods / trip. The most widely used fishing gears were gill nets $(44.14 \%)$ and fishing rods (43.25\%) (Table 2). Apart from these fishing gear, a small proportion of fishermen still use traditional tools such as arrows and spears and catch fish on the coast at low tide ("bameti"). Among the four types of fishing systems above, until now, it has survived and is still widely used by traditional fishers in Latdalam village. This is because the use of the three types of nets is economically more profitable.

Table 3.Number of Fishing Tools by Village in South Tanimbar District in 2018

\begin{tabular}{|c|c|c|c|c|c|c|c|}
\hline No & Village & \multicolumn{6}{|c|}{ Type of Fishing } \\
\cline { 4 - 8 } & Name & $\begin{array}{c}\text { Bea } \\
\text { ch } \\
\text { nets }\end{array}$ & $\begin{array}{c}\text { Gill } \\
\text { Net } \\
\text { Chart }\end{array}$ & $\begin{array}{c}\text { Se } \\
\text { ro }\end{array}$ & $\begin{array}{c}\text { Ser } \\
\text { o }\end{array}$ & $\begin{array}{c}\text { Bu } \\
\text { bu }\end{array}$ & $\begin{array}{c}\text { Fis } \\
\text { hin } \\
\text { g } \\
\text { rod }\end{array}$ \\
\hline 1 & $\begin{array}{c}\text { Latdala } \\
\text { m }\end{array}$ & - & 28 & 6 & 4 & 50 & \\
\hline 2 & $\begin{array}{c}\text { Lermata } \\
\text { ng }\end{array}$ & - & 23 & 4 & 4 & 34 & \\
\hline 3 & Matakus & - & 20 & 4 & 3 & 30 & \\
\hline 4 & Olilit & - & 20 & 2 & 2 & 27 & \\
\hline 5 & Bomaki & - & 18 & - & 1 & 28 & \\
\hline 6 & Sifnana & - & 12 & - & 2 & 25 & \\
\hline & Total & - & $\mathbf{1 2 1}$ & $\mathbf{1 6}$ & $\mathbf{1 4}$ & $\mathbf{1 9 4}$ & \\
\hline
\end{tabular}

Source: Maluku Tenggara Barat Dalam Angka (2018)

Based on the table above, it can be seen that the primary / dominant fishing gear used by fishermen in Latdalam village is generally still traditional, starting from other fishing tools, gill nets, and traps. Other fishing tools that are less in number are charts, scoops, and trawlers. This shows that fishers are only able to catch fish at specific depths and in certain seasons. In general, the revitalization of fishing gear is needed to empower fishers in Latdalam village.

Besides, their activities as fishermen with a sufficient amount of income, which they consider to be sufficient, have also been able to control them to survive and earn a fortune in their area, without having to move to other regions or even countries, let alone the distance between Latdalam village and East Leste. Moreover, Australia, which is not so far away, can provide opportunities for them to move.

\section{CONCLUSION}

1. The economic life of the community in Latdalam village, Tanimbar Selatan sub-district, as stated above, fishing activities as the main economic activity of the traditional coastal village community in Latdalam village, Tanimbar district, West Southeast Maluku, Maluku province, as well as other economic activities, grow. Moreover, develop mutually with the social and cultural aspects of the local community.

2. The marine fishery resource management system in Latdalam village can be seen in empowerment through the development of collective action, which 
means the development of cooperatives or joint business groups. Only here, the term used is collective action, namely to open opportunities for the community to form groups they want, which are not merely cooperatives or joint business groups. Collective action is a collective action that leads to the welfare of each member.

3. Traditional fishermen in Latdalam village still use traditional methods with traditional fishing equipment to catch fish because they protect the environment. Fishing gear is the essential equipment in the capture fisheries business. Tools are like life for fishers. Every fishing vessel naturally has relatively good availability of fishing gears in each fishing fleet, either using katinting boats or large vessels. Every ship should be equipped with fishing gear. It is strange if the boat or ship does not have minimum fishing gear. However, this fact is indeed found in the realities of the life of our coastal communities. Most small fishers only have katinting boats and fishing tools. Not a few small fishermen use their katinting boats not equipped with motorbikes, and even many fishers are without boats.

\section{ACKNOWLEDGMENT}

The author would like to acknowledge the Ministry of Higher Education, Science, Research and Innovation in providing the funding of this research project and to the Dean of Faculty of Social Science, Manado State University in supporting the publication of this article.

\section{REFERENCES}

[1] Sugiyono, Metode Penelitian Kuantitatif Kualitatif R\&D. Bandung: Alfabeta, 2011.

[2] W. Kymlicka, Kewargaan Multikultural. Jakarta: LP3ES, 2002.

[3] S. Hardjodinomo, Ilmu iklim dan pengairan. Penerbit Binacipta, 1975.

[4] A. Dasfordate, A. E. Pelealu, Y. Burdam, H. Terry, and A. Djarkasi, 'Pamaru Muka Pamaru Belakang: Tanimbar in the Shipping Network in Eastern Indonesia in the XIX Century', vol. 226, no. Icss, pp. 641-647, 2020.

[5] I. R. Smith, 'A research framework for traditional fisheries', 1979.

[6] D. Ticoalu, E. Reppie, and A. Telleng, 'Analisis Kebijakan Pemberdayaan Masyarakat Perikanan Tangkap di Kota Manado Policy analysis on fishing community empowerment in Manado City', J. Ilmu dan Teknol. Perikana, vol. 1, no. 3, pp. 76-80, 2013.

[7] N. I. K. M. R. Abdullah, 'and Iloilo, Philippines', Asian Fish. Sci., vol. 6, pp. 39-49, 1993.

[8] Y. Wahyudin, 'Sistem sosial ekonomi dan budaya masyarakat pesisir', Makal. disampaikan pada Pelatih. Pengelolaan Kaw. Konserv. Perairan, tanggal, vol. 5, 2003. 